\title{
Development of Brood-stock Diets for Nile tilapia Under Hapa-in-Pond Hatchery System; Optimal Dietary Vitamin C Level for the Optimum Reproductive Performance and Fry Survival
}

\author{
Ashraf Suloma', Al-Azab M Tahoun ${ }^{2}$ and Rania S Mabrok ${ }^{1 *}$
}

${ }^{1}$ Fish Nutrition Laboratory (FNL), Animal Production Department, Faculty of Agriculture, Cairo University, Giza, Egypt

${ }^{2}$ Department of Aquaculture Department, Faculty of Fish Resources, Suez University, Suez, Egypt

\begin{abstract}
The hapa-in-pond system is a hatchery technique, which, has been widely developed. In spite, of the research efforts in this field, little information is available considering the nutritional requirement of tilapia brood-stock under hapa-in-pond system hatchery technique and the effects on brood-stock reproductive performance and fry survival percentage. By taking in concern the previous points, five levels of vitamin $C(0 \mathrm{mg} / \mathrm{kg}, 200 \mathrm{mg} / \mathrm{kg}, 400 \mathrm{mg} / \mathrm{kg}$, $800 \mathrm{mg} / \mathrm{kg}$ and $1200 \mathrm{mg} / \mathrm{kg}$ ) were examined for its effect on reproductive performance of tilapia brood-stock and fry survival under the hapa-in-pond system conditions. Adult males and females with mean body weights of 198 $\mathrm{g}$ and $206 \mathrm{~g}$, respectively, with a male to female sex ratio of 1:2. Tilapia breeders were stocked at density $3 \mathrm{fish} /$ $\mathrm{m}^{3} ; 6$ (23:4 $\left./ \mathrm{hapa}\right)$. Tilapia brood-stock fed diet supplemented with Vitamin C (400 mg/kg) showed the highest reproductive performance results (total seed production; 8034 seeds; absolute fecundity of 2008.5 seeds female ${ }^{-1}$, relative fecundity; 7.57 seeds $\mathrm{g}$ female ${ }^{-1}$, and system productivity of 38.26 seeds day ${ }^{-1} \mathrm{~m}^{-2}$ ). While the lowest reproductive performance and fry survival percentage recorded for diet without Vitamin $\mathrm{C}$ supplementation. Fry survival results showed no significant among different diets supplemented with Vitamin $\mathrm{C}$, while the control recorded the lowest $(P<0.05)$ fry survival percentage. It could be concluded that, the optimal vitamin $C$ level for brood-stocks under conditions of hapa-in-pond hatchery system is $400 \mathrm{mg} / \mathrm{kg}$.
\end{abstract}

Keywords: Tilapia; Brood-stock; Vitamin C; Hapa-in pond system

\section{Introduction}

Developing of aquaculture sector guarantee a persistent source of protein subsequently avoids malnutrition that may occur with the continuous increase of population in developing countries. Tilapia is second after carp regarding the most farmed freshwater fish. Their positive aquaculture characteristics as fast growth, propensity to consume a variety of supplemental feeds, resistance to diseases and handling stress, easily reproduction in captivity and tolerant to wide range of environmental conditions are the reasons after the spread of their farming worldwide. Seed-stock supply is essential for the promotion of tilapia fish farming. Hapa-in-pond system is a popular hatchery technique for both breeding and nursing tilapia seed-stock $[1,2,3,4]$. High fry survival, low costs, and easy harvest are the technique advantages that lay after its spread in many countries as a production tool for tilapia seed stock [5]. Despite the research efforts in developing hapa in pond system technique, data shortage of nutrient requirement under the technique is one of the most important obstacles fronting the development [6]. Vitamin $\mathrm{C}$ is a micronutrient element and diet is the major source for Vitamin $\mathrm{C}$ for aquatic animals. Fish disable to synthesize Vitamin C. due to lack of gulonolactone oxidase enzyme. Vitamin $\mathrm{C}$ is involved in many metabolic bath ways in fish body as detoxification reaction, improve immunity response, steroid synthesis, vitellogenesis, collagen formation and stress tolerance [7]. Ascorbic acid has beneficial effects on growth of rainbow trout (Oncorhynchus mykiss) under the condition of hypoxia and normoxia. An increasing trend of ascorbic acid degradation in fish tissues was noticed under the condition of hyperoxia [8].

A dietary supplement of ascorbic acid has positive effects on reproductive performance in various fish species as it is involved in reproductive functions of fish tissues [9]. Vitamin $\mathrm{C}$ affects hormone synthesis, vitellogenesis, and results in variable oocyte AA retention and gamete quality [10]. $1250 \mathrm{mg} / \mathrm{kg}$ of Ascorbic acids improves the hatchability of Oreochromis mossambicus [11]. A dietary level of 375 $\mathrm{mg} \mathrm{AA} / \mathrm{kg}$ diet was suggested to near saturate the ovaries and optimize the reproductive performance of rainbow trout (Oncorhynchus mykiss) which was eight times higher than the level suggested the national research council. Fecundity and embryo survival also increased in female rainbow trout with increased dietary Vitamin C levels [12]. As for Nile tilapia (Oreochromis niloricus), the detected requirement of dietary ascorbic acid for was $50 \mathrm{mg} / \mathrm{kg}$ for fingerlings [13], while, there was no much information considering the brood-stock requirement. On the other hand, previous levels of Vitamin C requirements were concluded under clear water conditions. Meanwhile, some reports suggest that no need for dietary Vitamins supplementation under hapa-in-pond system (green water) because of natural food organisms which are rich in vitamins [14]. Thus the aim of our experiment was to determine whether dietary supplementation with vitamin $C$ is needed for Nile tilapia brood-stocks under conditions of hapa-in-pond system that may affect reproductive performance and fry survival rate.

*Corresponding author: Rania S Mabrok, Fish Nutrition Laboratory (FNL), Animal Production Department, Faculty of Agriculture, Cairo University, Gamma St., Giza, Egypt, Tel: +202-01001107273; Fax: 00202-35717355; E-mail: Rania.Ahmed@agr.cu.edu.eg

Received August 30, 2016; Accepted January 19, 2017; Published January 21 2017

Citation: Suloma A, Tahoun AM, Mabrok RS (2017) Development of Brood-stock Diets for Nile tilapia Under Hapa-in-Pond Hatchery System; Optimal Dietary Vitamin C Level for the Optimum Reproductive Performance and Fry Survival. J Aquac Res Development S2: 010. doi:10.4172/2155-9546.S2-010

Copyright: @ 2017 Suloma A, et al. This is an open-access article distributed under the terms of the Creative Commons Attribution License, which permits unrestricted use, distribution, and reproduction in any medium, provided the original author and source are credited. 
Citation: Suloma A, Tahoun AM, Mabrok RS (2017) Development of Brood-stock Diets for Nile tilapia Under Hapa-in-Pond Hatchery System; Optimal Dietary Vitamin C Level for the Optimum Reproductive Performance and Fry Survival. J Aquac Res Development S2: 010. doi:10.4172/21559546.S2-010

Page 2 of 4

\section{Materials and Methods}

Nile tilapia O. niloticus brood-stock were obtained from a commercial fish farm located in Kafr El-Sheikh Governorate, Egypt. A total number of 90 (30 male +60 female brood-stock) were selected and sexed and transferred to three $18 \mathrm{~m}^{3}$ conditioning hapas (each measuring $\left.6 \times 3 \times 1 \mathrm{~m}^{3}\right)$. The experiment was lasted for 105 days and conducted in 15 happas each of $2 \mathrm{~m}^{3}$ net volume $(2 \times 2 \times 0.5 \mathrm{~m})$ in an earthen pond $(1000 \mathrm{~m} 2)$. Both males and females tilapia brood-stock with mean body weights of (198 g and $206 \mathrm{~g}$ ) for group respectively, were stocked at a rate of $6\left(2 \delta^{1}: 4\right.$ 을 brood-stock hapa-1 with a male to female sex ratio of $1: 2$. At the end of the experiment, survival of stressed hatched larva has been detected.

\section{Experimental diets and feeding practices}

Five diets with different levels of supplemented Vitamin C $(0 \mathrm{mg} / \mathrm{kg}$, $200 \mathrm{mg} / \mathrm{kg}, 400 \mathrm{mg} / \mathrm{kg}, 800 \mathrm{mg} / \mathrm{kg}$ and $1200 \mathrm{mg} / \mathrm{kg}$ ) were formulated to examine the effect of different Vitamin $\mathrm{C}$ on reproductive performance of Nile tilapia brood-stock and fry survival (Table 1). The diets were prepared manually by mixing the requisite amount of dry ingredients thoroughly, followed by the addition of water to form thick dough. The experimental diets were pressure pelleted by house meat grinder and offered to fish in crumble form after grinding it.

Each experimental diet was allocated to three $2 \mathrm{~m}^{3}$ hapas according to a completely randomized design. Each hapa was considered as an experimental unit. During the experiment period (105 days), all fish were hand-fed at $2.5 \%$ feeding level three times a day on weekdays and once daily on weekends. Bulk weight of females and males in each hapa were recorded every 2 weeks.

\section{Fry survival}

Hatched fry from last clutch of different experimental treatments were examined for tolerance stress. As simulation to transport stress conditions, hatched fry from each treatment are distributed in three plastic bags. Plastic bags were aerated and then comparative survival percentages were estimated after six hours.

\section{Calculations and Statistical Analyses}

\section{Growth performance parameters}

The growth performance parameters were calculated according to the following equations:

Average weight gain $(A W G)=$ Average final weight $(g)-$ Average initial weight $(g)$ Average daily gain $(A D G)=[$ Average final weight $(g)$ - Average initial weight $(g)] /$ time $($ days $)$. Specific growth rate $(S G R)=100\left[L n W t_{1}-L n W t_{0} / T\right]$ Where:

Ln: normal $\log , \mathrm{Wt}_{0}$ : initial weight $(\mathrm{g}), \mathrm{Wt}_{1}$ : final weight $(\mathrm{g})$ and $\mathrm{T}$ : time of days

\section{Feed utilization parameters}

Feed utilization was calculated according to the following equation: Feed conversion ratio $(F C R)=$ Total feed consumption $/$ weight gain $($ male + female $)$

\section{Reproductive performance parameters}

Variables were estimated from the data included.

Absolute fecundity: The number of seeds per spawning per female.

Relative fecundity: The number of seeds per unit weight of female.

\section{Statistical Analysis}

The values of the means were statistically compared [15] with oneway ANOVA. Data were processed using SPSS software for Windows (version 17) [16].

\section{Results and Discussion}

Growth performance values of females fed different Vitamin C levels showed no differences. Meanwhile, males fed $400 \mathrm{mg}$ Vitamin $\mathrm{C}$ recorded the best growth performance values, Table 2 . The lowest growth performance was recorded for males fed control diet. Feed utilization was also noticed and the results suggested no significant

\begin{tabular}{|c|c|c|c|c|c|}
\hline Ingredient & Control & $\mathrm{C}_{200}$ & $C_{400}$ & $\mathrm{C}_{800}$ & $\mathrm{C}_{1200}$ \\
\hline Fish meal & 230 & 230 & 230 & 230 & 230 \\
\hline Poultry by product & 180 & 180 & 180 & 180 & 180 \\
\hline Soybean meal & 200 & 200 & 200 & 200 & 200 \\
\hline Corn grain & 230 & 229.8 & 229.6 & 229.2 & 228.8 \\
\hline Wheat bran & 100 & 100 & 100 & 100 & 100 \\
\hline Soybean oil & 30 & 30 & 30 & 30 & 30 \\
\hline Vitamin and mineral premix ${ }^{*}$ & 20 & 20 & 20 & 20 & 20 \\
\hline Carboxy-methyl cellulose & 5 & 5 & 5 & 5 & 5 \\
\hline $\mathrm{NaCl}$ & 5 & 5 & 5 & 5 & 5 \\
\hline Ascorbic acid & 0 & 0.2 & 0.4 & 0.8 & 1.2 \\
\hline Total & 1000 & 1000 & 1000 & 1000 & 1000 \\
\hline \multicolumn{6}{|c|}{ Analyzed composition (dry matter basis) } \\
\hline Dry matter (\%) & 92.5 & 92.1 & 92.3 & 92.2 & 92.5 \\
\hline Crude protein (\%) & 42.5 & 42.95 & 43.75 & 43.4 & 43.3 \\
\hline Lipid (\%) & 10.6 & 11 & 11 & 10.84 & 11.41 \\
\hline NFE $(\%)$ & 30.04 & 27.93 & 27.66 & 27.65 & 27.63 \\
\hline Ash (\%) & 9.36 & 10.22 & 9.89 & 10.31 & 10.16 \\
\hline Gross energy $\left(\mathrm{kcal} \mathrm{Kg}^{-1}\right)$ & 4643.38 & 4617.76 & 4651.22 & 4616.08 & 4663.51 \\
\hline
\end{tabular}

Vitamins and minerals mixture each $3 \mathrm{Kg}$ of mixture contains: 10,000,000 I.U. Vitamin A; 2,500,000 IU Vitamin D3; $10,000 \mathrm{mg}$ Vitamin E; $1000 \mathrm{mg}$ Vitamin K; $1000 \mathrm{mg}$ Vitamin B1; 5000 mg Vitamin B2; 1500 mg Vitamin B6; 10 mg Vitamin B12; 30,000 mg Niacin; 10,000 mg Pantothenic acid; 1000 mg Folic acid; 50 mg Biotin; 300 mg lodine; 30000 mg Iron; 60,000 mg Manganese; 4000 mg Copper; 100 mg Cobalt; 100 mg Selenium; 50,000 mg Zinc; 3000 g Calcium Carbonate.

Table 1: Composition and proximate analysis of different brood-stock diets $(\mathrm{g} / \mathrm{kg})$. 
Citation: Suloma A, Tahoun AM, Mabrok RS (2017) Development of Brood-stock Diets for Nile tilapia Under Hapa-in-Pond Hatchery System; Optimal Dietary Vitamin C Level for the Optimum Reproductive Performance and Fry Survival. J Aquac Res Development S2: 010. doi:10.4172/21559546.S2-010

Page 3 of 4

\begin{tabular}{|c|c|c|c|c|c|c|c|c|c|c|c|}
\hline $\begin{array}{c}\text { Vitamin C } \\
\text { levels }\end{array}$ & $\begin{array}{c}\text { Female } \\
\text { final } \\
\text { weight }(g)\end{array}$ & $\begin{array}{l}\text { Male final } \\
\text { weight }(g)\end{array}$ & $\begin{array}{c}\text { Female } \\
\text { weight } \\
\text { gain (g) }\end{array}$ & $\begin{array}{c}\text { Male } \\
\text { weight } \\
\text { gain (g) }\end{array}$ & $\begin{array}{c}\text { Average } \\
\text { hapa } \\
\text { weight gain } \\
\text { (g) }\end{array}$ & $\begin{array}{c}\text { Female } \\
\text { Daily } \\
\text { weight gain } \\
\text { (g) }\end{array}$ & $\begin{array}{c}\text { Male Daily } \\
\text { weight } \\
\text { gain(g) }\end{array}$ & $\begin{array}{l}\text { Total feed } \\
\text { intake (g) }\end{array}$ & $\begin{array}{c}\text { Feed } \\
\text { conversion } \\
\text { ratio }\left(\mathbf{g} \cdot \mathbf{g}^{-1}\right)\end{array}$ & $\begin{array}{c}\text { Female } \\
\text { specific } \\
\text { growth rate } \\
(\%)\end{array}$ & $\begin{array}{c}\text { Male specific } \\
\text { growth rate (\%) }\end{array}$ \\
\hline \multirow{2}{*}{ Control } & 325.67 & $331.00^{b}$ & 119.33 & $131.33^{b c}$ & $250.67^{\mathrm{ab}}$ & 1.14 & $1.25 b^{c}$ & 452.33 & 1.8 & $0.43 a$ & $0.48 a$ \\
\hline & \pm 3.18 & \pm 0.58 & \pm 2.19 & \pm 1.45 & \pm 3.53 & 0.02 & \pm 0.015 & \pm 4.33 & \pm 0.01 & \pm 0.01 & \pm 0.006 \\
\hline \multirow{2}{*}{200} & 325.67 & $332.67^{\mathrm{ab}}$ & 118.33 & $133.33^{\mathrm{ab}}$ & $251.67^{\mathrm{ab}}$ & 1.12 & $1.27^{\mathrm{ab}}$ & 445.33 & 1.77 & $0.43 a$ & $0.49 a$ \\
\hline & \pm 1.76 & \pm 1.20 & \pm 1.20 & \pm 0.33 & \pm 0.88 & 0.01 & \pm 0.003 & \pm 11.14 & \pm 0.04 & \pm 0.003 & \pm 0.000 \\
\hline \multirow{2}{*}{400} & 326.67 & $336.33^{a}$ & 122.67 & $136.33^{a}$ & $259.00^{a}$ & 1.17 & $1.30^{\mathrm{a}}$ & 449.33 & 1.74 & $0.45 a$ & $0.49 a$ \\
\hline & \pm 2.96 & \pm 1.76 & \pm 3.53 & \pm 0.33 & \pm 3.21 & 0.04 & \pm 0.000 & \pm 2.33 & \pm 0.03 & \pm 0.012 & \pm 0.003 \\
\hline \multirow{2}{*}{800} & 330.33 & $332.67^{a b}$ & 123.33 & $133.33^{\mathrm{ab}}$ & $256.67^{a}$ & 1.17 & $1.27^{\mathrm{ab}}$ & 444.33 & 1.73 & $0.44 a$ & $0.49 a$ \\
\hline & \pm 1.20 & \pm 0.67 & \pm 2.73 & \pm 0.33 & \pm 2.96 & 0.03 & \pm 0.003 & \pm 4.63 & \pm 0.02 & \pm 0.01 & \pm 0.003 \\
\hline \multirow{2}{*}{1200} & 323 & $324.33^{c}$ & 115.67 & $130.00^{c}$ & $245.67^{b}$ & 1.1 & $1.24^{c}$ & 445.67 & 1.81 & $0.42 a$ & $0.49 a$ \\
\hline & \pm 2.08 & \pm 2.03 & \pm 1.20 & \pm 1.53 & \pm 2.33 & 0.01 & \pm 0.015 & \pm 6.17 & \pm 0.01 & \pm 0.003 & \pm 0.008 \\
\hline
\end{tabular}

Table 2: Growth performance of tilapia brood-stock fed experimental diets.

\begin{tabular}{|c|c|c|c|c|c|}
\hline Vitamin C levels & Total seed production & $\begin{array}{l}\text { Absolute fecundity (Seed } \\
\text { Female }{ }^{-1} \text { ) }\end{array}$ & $\begin{array}{c}\text { Relative fecundity (Seed g } \\
\text { female }^{-1} \text { ) }\end{array}$ & $\begin{array}{l}\text { System productivity } \\
\left(\text { Seed day }{ }^{-1} \mathrm{~m}^{-2}\right)\end{array}$ & Fry survival \\
\hline Control & $7059.7^{c} \pm 141.4$ & $1764.90^{c} \pm 35.40$ & $6.64^{c} \pm 0.11$ & $33.62^{c} \pm 1.16$ & $91.13^{b} \pm 0.47$ \\
\hline 200 & $7490.3^{b} \pm 165.0$ & $1872.60^{\mathrm{b}} \pm 41.20$ & $7.03^{b c} \pm 0.17$ & $35.67^{b} \pm 1.36$ & $95.00^{\mathrm{a}} \pm 0.58$ \\
\hline 400 & $8034.0^{\mathrm{a}} \pm 141.2$ & $2008.50^{a} \pm 35.30$ & $7.57^{a} \pm 0.17$ & $38.26^{a} \pm 1.16$ & $94.60^{a} \pm 0.70$ \\
\hline 800 & $7464.3^{\mathrm{b}} \pm 37.0$ & $1866.10^{b} \pm 9.20$ & $6.95^{\mathrm{bc}} \pm 0.03$ & $35.54^{b} \pm 0.31$ & $96.00^{\mathrm{a}} \pm 0.58$ \\
\hline 1200 & $7657.3^{\mathrm{ab}} \pm 80.3$ & $1914.30^{\mathrm{ab}} \pm 20.10$ & $7.22^{\mathrm{ab}} \pm 0.10$ & $36.47^{\mathrm{ab}} \pm 0.66$ & $93.93^{a} \pm 0.93$ \\
\hline
\end{tabular}

Table 3: Reproductive performance of tilapia broodstock fed experimental diets.

differences among different treatments regarding feed intake and feed conversion ratio.

Reproductive performance of female tilapia brood-stock was reported in Table 3 . The highest total seed production (8034 seeds), absolute fecundity (2008.5 seeds female $\left.{ }^{-1}\right)$, relative fecundity (7.57 seeds $\mathrm{g}$ female $\left.{ }^{-1}\right)$ and system productivity $\left(38.26\right.$ seeds day $\left.{ }^{-1} \mathrm{~m}^{-2}\right)$ was recorded for diets supplemented with $400 \mathrm{mg} / \mathrm{kg}$ Vitamin C while the lowest values were recorded for the control (Table 3). As for fry survival, no differences among Vitamin C levels were observed while control showed the lowest fry survival percentage. Numerous studies showed the positive effect of Vitamin C dietary supplementation on reproductive performance of brood-stock. Generally L-ascorbic acid increases the maturation of germ cell which leads to increase milt quality such as sperm concentration, motility, duration and fertility [17]. A positive correlation between seminal plasma ascorbic and trout dietary ascorbyl monophosphate level was recognized by [18]. They also suggested that the deficiency effect of ascorbic acid in form of sperm concentration and motility may not recognized at the beginning of the spawning season but a decline in semen quality was recorded during experiment period. Subsequently, it was established that dietary Vitamin C may affect the fertilization process. An experimental diet supplemented with L-ascorbic acid improved sperm viability in grass carp Ctenopharyngodon idellus [17]. The Same finding was reported by [19]. Ascorbic acid plays a critical role in preventing endogenous oxidative DNA damage during spermatogenesis phase that could lead to genetic defects and low sperm quality in human [20].

Elevation of Vitamin C content in female gonads during maturation and its transfer from brood fish to be stored in eggs for supporting larval growth and development until first feed intake was reported by $[11,19,21]$ which may explain survival improvement recorded for diets supplemented with Vitamin C.

Ascorbic acid significantly affected the deposition of both lipids and the yolk protein precursor Vitellogenin. In presence of shortage yolk materials during maturation, a reduction in oocyte numbers, rather than a reduction in oocyte size was observed [10]. Ascorbic acid requirement of brood-stock could be indicated by the saturation level in mature ova. Meanwhile, $357 \mathrm{mg} / \mathrm{kg}$ ascorbic acid is required to obtain a $90 \%$ level of saturation and led to highest fecundity and embryo survival for rainbow trout (Oncorhynchus mykiss) [12]. The antioxidant effect of ascorbic acid seems to be critical for the genes integrity of fish gametes and decrease sperms DNA Fragmentation., meanwhile insufficient ascorbic acid lead to damage during mitotic division of germ cell $[9,22]$. Ascorbic acid is a leading nutrient in different tissue of reproductive system where interaction between catecholamine and steroid hormones that involved in gonad growth, acts as a regulatory mechanism of ascorbate absorption and metabolism in reproductive system [9].

Meanwhile, feeding tilapia brood fish $1250 \mathrm{mg} / \mathrm{kg}^{-1}$ of Vitamin $\mathrm{C}$ significantly improved fry survival compared with broodfish fed with $0 \mathrm{mg} / \mathrm{kg}^{-1}$ and $50 \mathrm{mg} / \mathrm{kg}^{-1}$ [19]. In the same context, live-bearing ornamental fish larva showed an increased survival rate in correlation with dietary ascorbic acid elevation [22]. Different doses of dietary Vitamin were suggested by many authors regarding Vitamin $\mathrm{C}$ form and life stage. Our results suggest that tilapia during the reproductive performance may require higher dietary supplementation of Vitamin C than in grow-out phase.

\section{Conclusion}

Brood-stocks fed diets supplemented with $400 \mathrm{mg} / \mathrm{kg}$ vitamin $\mathrm{C}$ showed the highest reproductive performance. No significant difference was recorded between brood-stock diets supplemented with vitamin $\mathrm{C}$ regarding fry survival rate while the control showed the lowest percentage. It seems that green water is not an adequate source of vitamin $\mathrm{C}$ for tilapia brood-stock and dietary vitamin $\mathrm{C}$ supplementation is needed. 
Citation: Suloma A, Tahoun AM, Mabrok RS (2017) Development of Brood-stock Diets for Nile tilapia Under Hapa-in-Pond Hatchery System; Optimal Dietary Vitamin C Level for the Optimum Reproductive Performance and Fry Survival. J Aquac Res Development S2: 010. doi:10.4172/21559546.S2-010

\section{References}

1. Mabroke RS, Tahoun AM, El-Haroun ER, Suloma A (2012) Influence of dietary protein on growth, reproduction, seed chemical composition and larval survival rate of Nile tilapia (Oreochromis niloticus) broodstocks of different size groups under hapa- in- pond hatchery system. Journal of The Arabian Aquaculture Society 7: 203-220.

2. Mabroke RS, Tahoun AM, Suloma A, El-Haroun ER (2013) Evaluation of Meat and Bone Meal and Mono-Sodium Phosphate as Supplemental Dietary Phosphorus Sources for Broodstock Nile Tilapia (Oreochromis niloticus) Under the Conditions of Hapa-in-Pond System. Turkish Journal of Fisheries and Aquatic Sciences 13: 11-18.

3. Tahoun AM, Mabroke RS, El-Haroun ER, Suloma A (2011) Effect of exogenous enzyme supplementation on reproductive performance of broodstock Nile tilapia reared in a hapa-in-pond hatchery system. In Proceedings of the 4th Global Fisheries and Aquaculture Research Conference, the Egyptian International Center for Agriculture, Giza, Egypt, 3-5 October 20112011 (pp. 61-73). Massive Conferences and Trade Fairs.

4. Khalfalla MM, Hammouda YA, Tahoun AM, Abo-State HAM (2008) Effect of broodstock sex ratio on growth and reproductive performance of blue tilapia Oreochromis aureus (Steindachner) reared in hapas. Proceedings of the 8th International Symposium on Tilapia in Aquaculture 2008: 115-125.

5. Lim CE, Webster CD (2006) Nutrient requirements. Tilapia biology, culture, and nutrition. Food Products Press, New York.

6. Bhujel RC, Yakupitiyage A, Turner WA, Little DC (2001) Selection of a commercial feed for Nile tilapia (Oreochromis niloticus) broodfish breeding in a hapa-in-pond system. Aquaculture 194: 303-314.

7. Chatakondi NG (2012) Transferring vitamin C from fish to embryos. International Aqua-feed Magazine. 15: 8-10.

8. Dabrowski K, Lee KJ, Guz L, Verlhac V, Gabaudan J (2004) Effects of dietary ascorbic acid on oxygen stress (hypoxia or hyperoxia), growth and tissue Vitamin concentrations in juvenile rainbow trout (Oncorhynchus mykiss). Aquaculture 233: 383-392.

9. Dabrowski K, Ciereszko A (2001) Ascorbic acid and reproduction in fish endocrine regulation and gamete quality. Aquaculture Research 32: 623-638.

10. Waagbø R, Hamre K, Maage A (2000) The impact of micronutrients on the requirement of ascorbic acid in crustaceans and fish. Ascorbic acid in aquatic organisms, status and perspectives. CRC Press LLC, Boca Raton, FL.

11. Soliman AK, Jauncey K, Roberts RJ (1986) The effect of dietary ascorbic acid supplementation on hatchability, survival rate and fry performance in Oreochromis mossambicus (Peters). Aquaculture 59: 197-208.

12. Blom JH, Dabrowski K (1995) Reproductive success of female rainbow trout (Oncorhynchus mykiss) in response to graded dietary ascorbyl monophosphate levels. Biology of Reproduction 52: 1073-1080.

13. Abdelghany AE (1996) Growth response of Nile tilapia Oreochromis niloticus to dietary L-ascorbic acid, L-ascorbic-2-sulfate, and L-ascorbyl-2-polyphosphate. J World Aquacult Soc 27: 449-455.

14. Bhujel RC (2000) A review of strategies for the management of Nile tilapia Oreochromis niloticus brood-fish in seed production systems, especially hapabased systems. Aquaculture 181: 37-59.

15. Duncan DB (1955) Multiple range and multiple $F$ tests. Biometrics.

16. SPSS (2007) Statistical package for social science (for Windows). Release 17 copyright, SPSS Inc., Chicago, USA.

17. Metwally MAA, Fouad IM (2009) Effects of L-ascorbic acid on sperm viability in male grass carp (Ctenopharyngodon idellus). Global Veterinaria 3: 132-136.

18. Ciereszko A, Dabrowski K (1995) Sperm quality and ascorbic acid concentration in rainbow trout semen are affected by dietary Vitamin C: An across-season study. Biology of reproduction 52: 982-988.

19. Gammanpila M, Age AY, Bart AN (2007) Evaluation of the effects of dietary vitamin $\mathrm{C}, \mathrm{E}$ and zinc supplementation on reproductive performance of Nile tilapia (Oreochromis niloticus). Sri Lanka Journal of Aquatic Science 12: 39-60.

20. Fraga CG, Motchnik PA, Shigenaga MK, Helbock HJ, Jacob RA, et al. (1991) Ascorbic acid protects against endogenous oxidative DNA damage in human sperm. Proceedings of the National Academy of Sciences, USA.

21. Seymour EA (1981) Gonadal ascorbic acid and changes in the level with ovarian development in the crucian carp, Carassius carassius (L.). Comp Biochem Physiol 70: 451-453.

22. Cabrita E, Martínez-Páramo S, Gavaia PJ, Riesco MF, Valcarce DG, et al. (2014) Factors enhancing fish sperm quality and emerging tools for sperm analysis. Aquaculture 432: 389-401. 